\title{
In search of sustainability: examining the variation in a national planning model when applied to different urban transport projects
}

\author{
L. Hansson \\ Swedish National Road and Transport Research Institute, Sweden
}

\begin{abstract}
How can we understand national planning model directives when they are implemented in local urban transport infrastructure projects? This paper concerns the application of the Swedish "four-stage principle", a model constructed by the Swedish Road Administration to identify investment priorities. A central aspect of this model is that new transportation investments must be compared with other investments, so that policy makers can reflect on and evaluate whether it is possible to use existing investments instead of starting new projects (in this lies the thought of sustainability). This paper aims to explain why implementation of a single national model, specifically, the four-stage principle model, varies in different urban transport infrastructure projects. The paper is based on a study of a Swedish county where three transport infrastructure projects have been evaluated. What role did the four-stage principle play in these processes? What barriers and opportunities are there to using this model? One conclusion is that the four-stage principle acquires different meanings and purposes in the projects, even though the projects are being implemented within the same policy area.
\end{abstract}

Keywords: urban governance, implementation, planning models, transport, sustainability.

\section{Introduction}

In striving for sustainability, national governments issue directives regarding how transport infrastructure should be planned and implemented. These directives are sometimes binding and sometimes only recommendations. To be effective, these directives need to be adopted and implemented by the local planners shaping urban transport systems. In Sweden, the "four-stage principle" 
model must be used when prioritizing new transportation investments. However, this model has been criticized for not being implemented as originally intended; instead, it has been applied in other urban transport areas. In this sense, the model has gained a broader purpose than it was originally designed for. In other cases, the model has simply been ignored. This paper aims to explain why implementation of a single national model, specifically, the four-stage principle model, varies in different urban transport projects.

\section{Theoretical point of departure}

The theoretical perspective takes departure in that a model may be adapted and implemented differently depending on the local context. Local organizations react to national-level plans, develop their own programs, and implement them; the national level can only partially and indirectly influence the local level. Most implementation problems arguably stem from the interaction between a policy and the local institutional setting $[1,2]$. Due to local contextual factors, locallevel implementation of a single national policy varies greatly [1]. One way to understand the different roles of a national model when implemented at the local government level is to study the governance structure found in the context where the model is imposed. Different governance structures may be found in a single urban system, depending on the sector in question. For example, one governance structure may be significant in elder care while the planning office uses another [3]. Hansson [4] has also demonstrated that different structures may coexist in the same policy area, since local organizational cultures create their own structures. The present study focuses on projects within one policy area, namely, urban transport, and the concepts of "hard" and "soft" governance structure are used to analyse the local planning context of each project. Hard governance structure emphasizes hierarchy and delegation of authority according to legislation or directives. Soft governance emphasizes policy implementation via networks [5], and central authorities direct local authorities by providing unofficial guidelines on how to improve local practice, instead of hierarchically determining what should be done [6]. Bottom-up researchers argue that the local level needs freedom to adapt programmes/models/directives to be implemented to local conditions, otherwise they are likely to fail [1]. In addition, the functions of binding versus nonbinding directives/rules are also used as explanatory variables. Binding directives are when national level requires the lower government level to fulfil the directive. While, nonbinding directives are voluntary for the lower level to apply. Directives of using the four-stage model are in some projects binding/mandatory and voluntary (i.e. non-mandatory) in others. National/international mandatory directives are arguably more likely to be applied in the local context than are non-binding directives. A soft governance approach is more likely to permit more local adaptation and directives are more open to local adaptation than are the directives in a hard governance structure [7]. However a soft governance structure is also more likely to create latitude for innovative practices in the implementation of directives, which can be adopted by central government and spread to other policy areas or authorities [6]. 


\section{Method and material}

Hjern's [8] method to studying implementation has inspired the research conducted here. Hjern and others after him (see e.g. [9]) focus on the local level, asking local actors about their goals, activities, and problems as well as analysing relevant documents concerning the studied process. This technique enables the researcher to map a network that identifies the relevant context for a specific policy at various levels (e.g. the local and national levels) and allows the researcher to examine both the strategic and unintended effects of policy implementation [1]. Three cases are analysed here; all are found in the same county, two located in a municipality and the third in a regional body. It was important to choose different types of project, since the local adaptation of the model may differ depending on project type. The first case is located at the municipal level and concerns a district renewal project. It is uncommon to use the four-stage principle model (4SP) in urban renewal projects, as the model is designed for prioritizing road and rail infrastructure, so it was interesting to understand how and why the model was applied to such a project. The second case concerns a road enlargement project located in the same municipality as the district renewal project. This project is one in which it would be more likely to find 4SP applied, since the model was originally intended for similar projects. However, it should be noted that neither the district renewal nor the road enlargement project imposes any binding requirements to use 4SP; doing so is purely voluntary. The third project is located at the regional level, where the planners must use 4SP, and concerns the planning process for formulating a county transport plan, which entails prioritizing infrastructural investments. To minimize context variation, it would have been preferable to find a municipal project in which 4SP use was mandatory but, as this was impossible, a regional project was chosen. The third project was chosen because of the binding requirements, but also because here the model is expected to be open to the least local adaptation, since it is constructed to be used in projects like this. In each case, several data sources has been collected and analysed, such as public documents, interviews, government reports, and website documentation. The use of a range of complementary sources is important, as it gives the researcher a better overview of the studied cases [10].

\section{Results}

\subsection{The four-stage principle model}

The four-stage principle model (4SP) was originally constructed by the Swedish Road Administration for managing investment funds, but has since been developed to a general planning model for managing resources and reducing the road transport system's negative effects. The Swedish Road Administration recommended that 4SP should be seen as "a general approach to analyses of road transport system measures and not as a strict model to be applied at specific planning stages" [11]. It is also stated that uses of this model encourages a more 
"creative way" of seeking solutions [12]. Use of the model at the local level is sometimes voluntary, while in other cases the national government level requires that the local level use the model, for example, when formulating the county transport plan, where project priorities had to be evaluated using 4SP.

A central aspect of this model is that new transportation investments must be compared with existing investments, so that policy makers reflect on and evaluate whether it is possible to use existing investments instead of starting new projects - in this lies the thought of sustainability. A basic consideration is that measures outside the road transport system can reduce the demand for road transport, and thus the need for new measures within the road transport system. As a first step, therefore, measures outside the road transport system should be considered. After that, the principle is largely concerned with analysing measures in the road transport system [11]. See Table 1 for the stages in the model.

Table 1: $\quad$ The 4SP process when evaluating projects.

\begin{tabular}{|c|c|c|}
\hline Step 1 & $\begin{array}{c}\text { Measures that affect } \\
\text { transport demand and } \\
\text { the choice of modes of } \\
\text { transport }\end{array}$ & $\begin{array}{c}\text { Covers planning, control, regulation, } \\
\text { effects, and information affecting } \\
\text { both the transport system and } \\
\text { society at large, to reduce the } \\
\text { demand for transport or transfer } \\
\text { transport to less space-consuming, } \\
\text { safer, and more environmentally } \\
\text { friendly modes }\end{array}$ \\
\hline Step 2 & $\begin{array}{c}\text { Measures that result in } \\
\text { more efficient use of the } \\
\text { existing road network }\end{array}$ & $\begin{array}{c}\text { Covers input in terms of control, } \\
\text { regulation, effects, and information } \\
\text { concerning the various components } \\
\text { of the road transport system, to use } \\
\text { the existing road network more } \\
\text { efficiently and safely and in a more } \\
\text { environmentally friendly way }\end{array}$ \\
\hline Step 3 & $\begin{array}{c}\text { Road improvement } \\
\text { measures }\end{array}$ & $\begin{array}{c}\text { Covers improvement measures and } \\
\text { rebuilding of existing segments, for } \\
\text { example, traffic safety measures or } \\
\text { load-bearing capacity measures }\end{array}$ \\
\hline Step 4 & $\begin{array}{c}\text { New investment and major } \\
\text { rebuilding measures }\end{array}$ & $\begin{array}{c}\text { Covers rebuilding and new building } \\
\text { measures, which often demand new } \\
\text { land, for example, for new road } \\
\text { segments }\end{array}$ \\
\hline
\end{tabular}

Source: [11]

The model is based on the argument that any potential improvement in the transport system should be examined in stages. The challenge is to find the best course of action by which to resolve problems or deficiencies in the system. The four-stage principle model was introduced in the early 00s and assumes that the transport system will be designed and developed based on a holistic approach. 
Appropriate solutions to problems will be discussed and analyzed in an unbiased way in the early stages of planning and before possible solutions have been considered [13].

\subsection{Different projects and different governance approaches}

The first project is referred to as the "district renewal project". Its aim is to reshape the inner city into a more attractive, creative and modern city centre, including the attempted integration of transportation modes, where travel by public transport should be the foundation. This project emphasized sustainability considerations from the outset [14]. In addition, the planning and working process of the district renewal project includes many elements of creativity and new thinking. The planners come from various professions and are initiating activities that go beyond the traditional planning process. For example, the planners decided to invite artists to participate in the planning process:

Invite artists to work in teams and contribute ideas for complex infrastructure projects. ... And to work experimentally with a lighter form of urban development... [15].

The planners have taken an open-minded approach to the public. The project has its own website, which is very colourful and includes high-definition pictures of the involved public officials and clear contact information, in case members of the public have any questions. The project also includes an exhibition space where models of the future urban renewal project can be seen and to which school classes are invited for guided tours [16].

The second project is referred to as the "road enlargement project". It is located on the outskirts of the city and its aim is to enlarge an existing road by adding traffic lanes and broadening parts of the existing lanes. The project reflects the municipality's vision to redirect cars from the city centre to the outskirts of the municipality by constructing an improved route for heavy vehicles and commuter traffic [17]. The planning process for the road enlargement project has been very protracted: the project has been discussed in the municipality for approximately 15 years and has been on the political agenda many times without a decision being reached [18]. This process can be viewed as more of technocratic, with a strong focus on using more traditional planning approaches i.e. relying on standard proceedings and documents, compared with the district renewal project. The planners working on the road enlargement project are located in the municipal administration, but some technical consultants are involved as well [18]. The project team is more homogeneous in professional composition than in the district renewal project. In addition, the project webpage is linked to the municipality's website, where the project is listed as one of several infrastructure projects. In this project, the planning documents are also emphasized when approaching the public, and accompanying descriptions of the overall vision are limited. Contact information is provided on the webpage and mandatory public consultations were held with interested citizens, but no further outreach (e.g. school tours) is encouraged. 
The third case concerns a regional project and is referred to as the "county transport plan". Work on this plan should result in a list that identifies the infrastructural projects to be prioritized in the county. This prioritizing should be done by taking account of 4SP [19]. The planning process for the county transport plan is similar in some respects to the road enlargement project, in that it is a fairly traditional technocratic process. The organization prepared for the planning work well in advance, mainly internally in the regional county organization without any political controversies, though municipal officials have been involved in consultations. The characteristics of these three projects are summarized in Table 2.

Table 2: $\quad$ Project characteristics.

\begin{tabular}{|c|c|c|c|}
\hline $\begin{array}{c}\text { Overall } \\
\text { purpose of the } \\
\text { project }\end{array}$ & $\begin{array}{c}\text { District } \\
\text { renewal } \\
\text { "Central" } \\
\text { function for the } \\
\text { city- } \\
\text { sustainability }\end{array}$ & $\begin{array}{c}\text { Road } \\
\text { enlargement } \\
\text { "Support" } \\
\text { function for the } \\
\text { city }\end{array}$ & $\begin{array}{c}\text { County transport } \\
\text { plan }\end{array}$ \\
\hline $\begin{array}{c}\text { Type of } \\
\text { planning } \\
\text { process }\end{array}$ & $\begin{array}{c}\text { Creative, } \\
\text { prioritizing } \\
\text { infrastructure } \\
\text { investment }\end{array}$ \\
\hline $\begin{array}{c}\text { Proposed } \\
\text { transport } \\
\text { mode }\end{array}$ & Public transport & $\begin{array}{c}\text { Technocratic, } \\
\text { traditional, } \\
\text { politicized }\end{array}$ & $\begin{array}{c}\text { Technocratic, non- } \\
\text { political, well } \\
\text { prepared }\end{array}$ \\
\hline $\begin{array}{c}\text { External } \\
\text { approach }\end{array}$ & Oppen process, & cars & $\begin{array}{c}\text { Road and rail } \\
\text { investments }\end{array}$ \\
\hline
\end{tabular}

Applying the governance structure concepts to the project characteristics, one can conclude that the district renewal project incorporates elements of soft governance, with network and innovative thinking at the centre. The road enlargement project and county transport plan, on the other hand, have more hard governance characteristics, the projects being conducted mainly by public planners within the organizations and not in a network of various types of actors. Turning to 4SP, it is important to identify the mandatory/non-mandatory element of the model in the projects. In both the district renewal and road enlargement projects, the use of 4SP is not mandatory; instead, it is the local organizations that must propose that this model be applied. In the county transport plan, on the other hand, 4SP is mandatory, and binding directives from the national government level state that the model must be used (see summary, Table 3).

Table 3: $\quad$ Type of governance structure related to 4SP requirements.

\begin{tabular}{|c|c|c|}
\hline & 4SP mandatory & 4SP not mandatory \\
\hline Soft governance & & District renewal \\
\hline Hard governance & County transport plan & Road enlargement project \\
\hline
\end{tabular}




\subsection{Local adaptation of the 4SP model}

The district renewal, road enlargement, and county transport plans each have different governance structures, the first displaying more soft governance characteristics and the last two more hard governance characteristics. As will be demonstrated, the application of the model also differs within each project.

In the district renewal project, 4SP is promoted and almost commercialized outside the project group. For example, the public can attend seminars in which 4SP is described in relation to the district renewal project [20]. In addition, leaflets are published and distributed stating that 4SP will be used in the district renewal project (see e.g. [21]). When it comes to the road enlargement project, 4SP is not "commercialized" or used to promote the project. It is stated on the project website that 4SP has been used, but that there are no public seminars or leaflets concerning it. This signals a difference between the projects. In the district renewal project, 4SP has a broader purpose than merely serving as a decision making tool; it also serves to indicate that the project is striving for sustainability, the application of the model being one step in this direction. A public document states the role of 4SP as:

“...through the systematic use of 4SP, methods for implementing new sustainable transport solutions that support local community planning should be developed" [22].

Hence, 4SP is useful as an innovative process and is seen as one component in the creation of a new planning method for reaching sustainability. In the district renewal project, the use of 4SP also emphasizes dialogue and collaboration between various actors, the aim of this dialogue is to gain and transfer experience [22].

The road enlargement project places less emphasis on networks and can be classified as part of a more technocratic planning tradition. The municipal planners have the main role in this project, and consultant engineers are the main source of outside influence. Despite claims on the project website, 4SP is barely applied in this project. One planner who works on the road enlargement project stated: "We don't use the model in this project; other infrastructure projects in the municipality use it, but not us" [23]. His colleague, on the other hand, argued that 4SP was very relevant to this project, since it demonstrated that the plan redirected the car traffic from the inner city by enlarging the road. In this way, alternative traffic modes elsewhere in the municipality (mainly in the city centre) were prioritized by focusing on the heavy traffic [18]. Later, however, the same informant argued that other transport modes alternatives had not been specifically evaluated in this project. It is difficult to determine whether 4SP was actually used in this sense, as other data (e.g. documents and interviews) provide no indication that it was. Perhaps it was relevant to the project, as one interviewee claimed, but some of the data do not indicate this. Instead, other planning models such as an environmental impact assessment model were used 
and the analysis of alternative transport modes, etc., was not included in this process [18].

The county transport plan also involves numerous planning elements, one being the environmental impact assessment model and 4SP another. The Swedish Road Administration has requires that regional planners must account for 4SP in their planning processes. Analyzing the work on the county transport plan, it became evident that the model was being used, but not integrated into the planning process as it had been in the district renewal project. Instead, the regional planners had already started their process by evaluating projects for prioritizing before the Swedish Road Administration imposed the 4SP requirements [24].

The regional planners decided that, despite their existing evaluation, they would try to apply 4SP; accordingly, they hired a consultant to conduct the evaluations for them. The consequence it got using this approach was that 4SP was implemented in parallel with the original planning process. The consultant firm came up with several prioritizing suggestions according to steps 1 and 2 of 4SP. The existing prioritization in terms of infrastructural projects was not changed, but additional projects concerning bike routes, public transport, etc., were identified as prioritized objects. The results of the regional planners' work with 4SP in the county transport plan can serve to exemplify local adaptation of the model related to binding national requirements. The regional organization did not integrate the model throughout the process, since its own process had started before the requirements had been imposed by the national level, but it managed to conduct a parallel process and, in this way, adapt the model to the planning context appropriate for them.

So far I have discussed three projects in the local context and how they did or did not apply 4SP. When seeking to understand the application of 4SP, one must also consider the role of the relevant senior level of government in the process. In the district renewal and road enlargement projects, the senior government level was represented by the regional actors. In the county transport plan, the senior government level was represented by the national government actors. In addition, we can discern differences in the senior government level role, in terms of both who takes the initiative to apply 4SP and who is involved in actually implementing the model.

In both the road enlargement and district renewal projects, there was no requirement from the senior government level to use 4SP; its use was instead voluntary. However, the regional body (which was the senior government level in the first two projects) took a more active role in advocating 4SP in the district renewal project, compared with its role in the road enlargement project. In the district renewal project, the regional actors together with the municipality made an EU application, to raise additional funds for testing 4SP in a district renewal project and to make the model applicable at the local level. The application was accepted. In the road enlargement project, the specific project was identified as prioritized at the regional level, and was investing in a small part of the project. Was 4SP used at the regional level to prioritize the project, so was 4SP actually applied in the road enlargement project but by an actor outside the municipality? 
If so was the case, this could have explained why 4SP was not used in the road enlargement project in the municipality. However, interviewing the planner at the regional level made it clear that $4 \mathrm{SP}$ also played a very small role when it came to the prioritizing (see the third project examined here, the county transport plan). This means that 4SP also played a small role at the regional level in work related to the road renewal project.

In the county transport plan, the senior government level was the Swedish Road Administration. Its role vis-à-vis the regional planners can be described as steering at a distance. The national level played a large role in the county transport plan in that it demanded that regional planners use 4SP. However, actual national-level involvement in the county transport planning process has been minimal: national actors provided courses for planners on how to apply 4SP, but have not been directly involved as in the district renewal project.

The 4SP model was applied differently in the three projects (see summary, Table 6).

Table 6: $\quad$ The 4SP model applied in the local context.

\begin{tabular}{|c|c|c|c|}
\hline & $\begin{array}{l}\text { District } \\
\text { renewal }\end{array}$ & $\begin{array}{c}\text { Road } \\
\text { enlargement }\end{array}$ & $\begin{array}{c}\text { County } \\
\text { transport plan }\end{array}$ \\
\hline $\begin{array}{c}\text { Governance } \\
\text { structure }\end{array}$ & $\begin{array}{c}\text { Soft } \\
\text { governance }\end{array}$ & Hard governance & Hard governance \\
\hline $\begin{array}{c}\text { Mandatory/non- } \\
\text { mandatory }\end{array}$ & $\begin{array}{c}\text { Non- } \\
\text { mandatory }\end{array}$ & Non-mandatory & Mandatory \\
\hline Model purpose & $\begin{array}{c}\text { Test new } \\
\text { approaches }\end{array}$ & None & $\begin{array}{c}\text { Gain a broader } \\
\text { overview, } \\
\text { mandatory }\end{array}$ \\
\hline $\begin{array}{c}\text { Model } \\
\text { introduction }\end{array}$ & Early & Midde-late & No initiative \\
\hline $\begin{array}{l}\text { Senior-level } \\
\text { government } \\
\text { involvement }\end{array}$ & High & Low & Low/distance \\
\hline $\begin{array}{c}\text { Model } \\
\text { application }\end{array}$ & Integrated & Not applied & Parallel process \\
\hline
\end{tabular}

It can be concluded that the 4SP was not used in the road enlargement project; instead, other models, such as an environmental impact assessment model, were applied. In the county transport plan, the 4SP was applied but it was introduced late in the project and the 4SP work became a parallel process to the existing process. In the district renewal project the model was the most integrated into the process; though it was not mandatory that the project use the model, it was here that its application was most integrated.

\section{Conclusion}

National models are open to local adaptation when applied in local contexts. This paper has demonstrated that implementation of a single national model, 
specifically, the four-stage principle model (4SP), varies in different urban transport projects (see Table 6 for an overview of the different model applications).

It can be concluded that the governance structure matters for how the model is applied in urban transport projects. A soft governance structure, found in the district renewal project, seemed more open to integrating 4SP into the planning process than were the hard governance structures of the other two projects. Other studies have demonstrated that soft governance allows greater latitude for new thinking - one possible explanation for why the model was applied here. Another possible explanation related to soft governance structure concerns the district renewal project network interactions with the regional level, where various actors combined their efforts in an initiative to test the model. However, besides governance structure, other factors also affected model application, the main being whether use of the model was mandatory. This was evident in projects with a hard governance structure; here the model was applied when it was mandatory (i.e. in the county transport plan project). However, the application differed from in the district renewal project, in that the use of the model in the county transport plan became a parallel process to the original planning process.

The model acquired different meanings in the different projects in which it was applied. In the district renewal project, the model became a link between various actors in the urban transport system, while in the county transport plan, the model was used only for its originally intended purpose, namely, for discussing alternative priorities.

Finally, it is also important to point out that 4SP was just one of several models used in planning the projects. Multiple models exist in urban transport planning; for example, an environmental impact model played a large role in the road enlargement project, where interviewees argued that it was more relevant than was 4 SP.

\section{Acknowledgements}

This study is founded by the Swedish National Road and Transport Research Institute. The study is part of a larger multi-disciplinary research project concerning decision making and energy efficiency. A special thank goes to the members of the project group: Annelie Carlson, Anna Melin and Lennart Folkesson.

\section{References}

[1] Matland, R.E. Synthesizing the Implementation Literature: The Ambiguity-Conflict Model of Policy Implementation. Journal of Public Administration Research and Theory. 5 (2) 145-174, 1995.

[2] Berman, P. The Study of Macro- and Micro- Implementation. Public Policy 26 (2) $157-184,1978$.

[3] Pierre, J. Models of Urban Governance: The institutional Dimensions of Urban Politics. Urban Affairs Review. 34:372-395, 1999. 
[4] Hansson, L. Hybrid steering cultures in the governance of public transport: - a successful way to meet demands? Proceedings of the Twelfth International Conference International Conference on Competition and Ownership in Land Passenger Transport. 2011.

[5] Montin, S., Hedlund, G. Governance på svenska. Santérus Academic Press Sweden: Stockholm. 2009.

[6] Brandsen, T., Boogers, M., Tops, P. Soft Governance, Hard Consequences: The Ambiguous Status of Unofficial Guidelines. Public Administration Review. 66 (4) 546-553, 2006.

[7] Egeberg, M., Martens, M., Trondal, J. Building Executive Power at the European Level. On the role of EU-level agencies. ARENA Working Paper. No. 10. Oslo University. 2009.

[8] Hjern, B. Implementation Research: The Link Gone Missing. Journal of Public Policy. 2 (3) 301-308, 1982.

[9] Hupe, P. The Thesis of Incongruent Implementation: Revisiting Pressman and Wildavsky. Public Policy and Administration 26 (1) 63-80, 2011.

[10] Yin, K. Case study research: designs and methods. Thousand Oaks: Sage Publications. 3rd edn. 2003.

[11] Swedish Road Administration 2002:72 Analysis of Measures in accordance with the Four-stage Principle: a general approach to analyses of measures for the road transport system. 2002. (Agency Report).

[12] Prop. 2008/09:35 Framtidens resor och transporter: infrastruktur för hållbar tillväxt. 2008.

[13] Boverket. Att samordna kommunal planering med utbyggnad av vägar och järnvägar- exempel och reflektioner. 2009. (Agency Report).

[14] Region Skånes Verksamhetsprogram för Hållbar stadsutveckling. 2011. (Public document B)*

[15] Municipal protocol, 2011-04-06 (Public document C)*

[16] Municipal Press release, 2011-03-18 (Public document B)*

[17] Interview B. Former municipal official. 2011-11-02*

[18] Interview C. Municipal official. 2011-11-02*

[19] Regional transportinfrastrukturplan för Skåne 2010-2021. 2010. (Public document A)*

[20] Invitation to seminar. Regionkontoret syd. No date. (Public document A)*

[21] Flyer. Regionkontoret syd: Fyrstegsprincipen i nya stadsdelar. No date. (Public document A)*

[22] Steering group urban renewal. Municipal protocol, 2010-03-02. 2010. (Public document A)*

[23] Interview A. Municipal official. 2011-10-19*

[24] Interview D. Regional official. 200-11-01*

* In order to secure the interview persons' anonymity, the empirical sources have been anonymized according to a code chart. To request full data information, please contact the author. 